\title{
Measuring the Informal Economy in South Africa
}

\author{
Stephen Saunders
}

Monash University

Elsabé Loots

University of the Free State

\begin{abstract}
Measuring the size of the South African informal economy has received inadequate attention, making it difficult for policy-makers to assess the impact of policy measures to stimulate informal economic activity. This article aims to estimate the size of the informal economy by using the Currency Demand Approach. The empirical results reveal that the informal economy as a percentage of GDP decreased from 1967 to 1993, before levelling off. The growth in the informal economy has also underperformed in comparison to formal economic growth. There appears to be a causal relationship running from the informal to the formal economy. Macro-economic policies aimed at the formal economy will not necessarily 'trickle down' to the informal, while these policies aimed at the informal economy may have a profound effect on the formal economy.
\end{abstract}

JEL C22; E01

\section{1}

\section{Introduction}

There has recently been a revival of interest in the nature and characteristics of the informal economy in developing countries. This has been driven by the increase in the size, in absolute terms, of the informal economy, and by the increasingly important role that informal economic activity can play in the generation of income-earning opportunities in developing countries (Schneider \& Enste, 2003).

South Africa is no exception to this trend. Estimates show that the participants in the informal economy have increased from 1.9 million in 1992 to 3.5 million in 2002, an increase of roughly 84 per cent (Quantec, 2003). The increase in informal activity should be seen against the background of the declining labour force absorption rate of the formal economy from 82.1 per cent in 1981 to 38.2 per cent in $2002^{2}$ - and the exceptionally high level of unemployment. According to the latest Labour Force Survey (StatsSA, 2004), it is estimated that the unemployment rate ranges between the strict definition estimate of 27.8 per cent and an expanded definition estimate of 41.2 per cent.

While the recent literature on the informal economy in South Africa has focused predominantly on the nature and characteristics of the informal economy (see Schaefer, 2001 and Devey, Skinner \& Valodia, 2003 for a detailed analysis), the research on quantifying the contribution by the informal economy to the gross domestic product over time has been limited. As a result, policy-makers often have to rely on irregular point estimates of the informal economy. Some examples of point estimates of the informal economy include the studies by Van der Berg (1990) and Hartzenberg \& Leimann (1992), which used the Currency Demand Approach and concluded that the informal economy accounted for 9 per cent of GDP in 1989. Using a labour market approach for the same period, Loots (1991) estimated that the contribution of the informal economy was higher at 12.6 per cent of GDP. Martins and Ligthelm (1995: 14), using the October Household Surveys for 1993 and 1994, estimated that the informal economy accounted 
for 9.2 per cent of GDP in 1993, and for 6.7 per cent in 1994. Using the five-yearly survey of Income and Expenditure of Households, Prinsloo (1999: 27) estimated the size of the informal economy in 1999 to account for approximately 7 per cent of GDP. One of the few time series estimates of the informal economy is the study by Abedian \& Desmidt (1990). They used a theoretical construct to approximate the trends of informal income as a percentage of GDP. The study shows that while the number of participants in the informal economy increased substantially during the period 1970 to 1988 , the informal economy per se only increased from around 6 per cent of GDP in 1970 to approximately 12 per cent in 1988.

While these and other studies were useful in highlighting the important role of the informal economy at that particular time, and although point estimates for the informal economy are now included in South African gross domestic product figures $^{3}$, there have been few recent attempts to estimate time series data on the contribution of the informal economy in South Africa.

This article outlines the various measurement approaches that have been used in the recent international literature on the informal economy, and it explains why the Currency Demand Approach is probably useful in the South African context. The methodology of this approach is then described, and the model to be used is specified. The size of the informal economy is then estimated, followed by a comparison of the growth in the formal and informal economies as well as the relationship between these two sectors.

\section{2}

\section{Approaches to measure the informal economy}

Tanzi (1982) suggests that the size of the informal economy can be quantified in three very different ways. Firstly, there is pure speculation where the informal economy is quantified by various interest groups and institutions to increase the awareness that the phenomenon exists and that it needs to be considered in the decision-making process. Secondly, educated guesses advance figures based on some more or less coherent reasoning, but these figures are not well defined, or indeed, incomparable to other statistics. Lastly, there are the well-defined, unambiguous approaches, which do allow comparisons to be made between different time periods, or between the informal economies of different countries. The international literature on informal economies is predominantly focused on these well-defined approaches. The well-defined approaches can be broadly sub-divided into the direct approach, the model approach and the indirect approach.

In the direct approach, the amount of undeclared taxable income is measured. This is used, in turn, to estimate the size of the informal economy. The direct approach relies on well-designed surveys and samples that are based on tax audits and voluntary responses, amongst other sources of data (Schneider \& Enste, 2003).

The so-called model approach examines a number of exogenous and endogenous variables that lead to the existence and growth of the informal economy over time, and in so doing, infers the size of the informal economy over time (see Giles, Tedds \& Werkneh, 1999 and Frey \& Schneider, 2000).

The indirect approach uses secondary data sources to (indirectly) estimate the size of the informal economy. Currently, there are five different indicators that can act as indicators of the size of the informal economy:

- In the Discrepancy Approach, the discrepancy between the estimates of gross domestic product according to the expenditure approach and the income approach may be attributed to the (unobserved) informal economy (Hartzenberg \& Leimann, 1992).

- In the Labour Discrepancy Approach, the discrepancy between the official and the actual labour force statistics may be attributed to the fact that people work in the informal economy (Loots, 1991).

- In the Transactions Approach, which assumes that there is a constant relationship 
between volume of transactions and the gross domestic product; any discrepancy or change in that ratio is seen as being caused by the informal economy (Tanzi, 1999).

- In the Electricity Consumption Approach, it is assumed that electric power is the single best physical indicator of overall economic activity: any discrepancy between actual electricity consumption and usage patterns and official projections is caused by the informal economy (Dobozi \& Pohl, 1995 and Lacko, 1998).

- In the Currency Demand Approach, currency demand is estimated in order to assess the size of the informal economy (Bagachwa \& Naho, 1995 and Schneider \& Enste, 2003).

\section{3}

\section{The currency demand approach}

Many of the approaches referred to above are suitable for use in estimating the informal economies of developing countries such as South Africa. In the case of South Africa, the Currency Demand Approach seems appropriate for a number of reasons. Firstly, it could be assumed that informal sector participants use predominantly cash to finance their transactions. Secondly, it is easy to use in a simple ordinary least-squares model that allows for a stepwise analysis of the explanatory variables. Thirdly, the same approach has been used successfully in the context of other developing countries, specifically in Africa (Bagachwa \& Naho, 1995 and Schneider \& Enste, 2003). Finally, a model of the Currency Demand Approach is capable of producing time series estimates of the informal economy. These can be used to test the relationship between the formal and informal economy in South Africa.

\subsection{Method}

The two key assumptions of the Currency Demand Approach are that the informal economy uses currency to conclude transactions and that the velocity of money in the informal economy is the same as that in the formal economy ${ }^{4}$.

A multiple regression analysis is used to estimate a currency demand function in order to estimate the size of the informal economy. Within the broad framework of the general functional form, alternative variables and proxies were used during trial estimations. Other functional forms such as linear-linear, log-linear, and linear-log were also used in the trial stage. However, only the estimations using $\log -\log$ are presented in the study since they provided the best fit. The present analysis is based on annual data obtained from the South African Reserve Bank for the period 1966-2002.

The model that can be used to estimate the size of the informal economy may be specified as follows:

$Y=f\left(X_{1}, X_{2}, \mu\right)$

Where $\mathrm{Y}$ is the dependent variable, representing the ratio of currency in circulation outside the banks to narrowly defined money supply; $\mathrm{X}_{1}$ is the set of traditional independent variables considered to be the major determinants of $\mathrm{Y}$; $\mathrm{X}_{2}$ is the proxy variables that stimulate informal economic activity; and finally, is the $\mu$ stochastic error term.

One of the major shortcomings of using the monetary aggregates to estimate the informal economy is that all changes in the ratio of cash holdings to money supply are attributed to changes in the informal economy. Such an approach is only reasonable if no other factors have an influence on the ratio. However, there are a number of other factors that would influence the ratio of cash holdings to money supply. These other factors are represented in the model by a number of variables, such as: the proportion of final consumption expenditure by households in national income (to capture changing payment and moneyholding patterns); the nominal interest rate (to capture the opportunity cost of holding cash); the general government tax index (to capture government intervention); and a time trend variable (to capture the modernisation of the economy and the increased sophistication of the banking system). 
When the variables that stimulate the informal economy $\left(\mathrm{X}_{2}\right)$ are assigned to zero, the regression equation yields the estimate of the demand for currency of the formal economy. When the variables that stimulate the informal economy are assigned their values, the regression equation yields the estimate of the demand for currency of both the formal and informal economies. The difference between the two estimates can then be used as an indication of the currency held in the informal economy. When multiplied by the velocity of money, an indication of the size of the informal economy can be derived.

The equation for the demand for currency in South Africa (1966-2002) is initially specified as:

$1 \mathrm{n}(N C M)_{t}=\beta_{0}+\beta_{1} 1 \mathrm{n}(G R)_{t}+\beta_{2} 1 \mathrm{n}(W S)_{t}+$ $\beta_{3} \ln (R)_{t}+\beta_{4} \ln (Y N)_{t}+\beta_{5} \ln (G)_{t}+\beta_{6} \ln (T)_{t}$

$+\mu_{t}$

with

$\beta_{1}>0, \beta_{2}>0, \beta_{3}<0, \beta_{4}>0, \beta_{5}, \beta_{6}>0$

where $\ln$ is the natural $\log$; NCM represents the ratio of notes and coins holdings to narrow money supply; GR the ratio of government revenue to GDP; WS the proportion of final consumption expenditure by households to gross domestic product; $\mathrm{R}$ the nominal interest rate; $Y N$ the real per capita income; $G$ the general government tax index; $\mathrm{T}$ the time trend to proxy the modernisation of the economy and the increased sophistication of the banking system; and $\mu_{2}$ the stochastic error term, respectively. This equation for the demand for currency is an adaptation of the equation used by Bagachwa \& Naho (1995).

The velocity of money can be defined formally as the ratio of income to the quantity of money:

$V=\frac{Y}{C}$ or $V=\frac{Y}{M_{1}}$

where $\mathrm{Y}$ represents gross domestic product, $\mathrm{C}$ is the sum of currency, and $\mathrm{M}_{1}$ is narrowly defined money supply.

Before examining the model specification it must be mentioned that the plausibility of the results depends on the stability and robustness of the money demand equation. While previous studies in other countries have suggested that the equation is stable and robust, it is unclear if this is the case in South Africa (Schneider \& Enste, 2003).

\subsection{Model specification}

Using equation 2 , the size of the informal economy for the period 1967-2002 can be estimated using EViews (2000).

The initial model showed that the estimated coefficients for the least squares regression were all statistically significant at a 5 per cent level, with a t-statistic value in excess of two (except for WS). The overall regression fit, as measured by the adjusted $\mathrm{R}^{2}$ value, indicated that 93 per cent of the variation in the currency demand was explained by the independent variables. The overall f-statistic showed a value of 86.98 , indicating that the model was significant at a 1 per cent level. However, additional analysis was necessary because of the low value of the DurbinWatson statistic of 1.21. The low value of the Durbin-Watson statistic was indicative of the presence of serial correlation in the residuals of the estimates equation.

While the Durbin-Watson statistic can often be difficult to interpret, a more general BreuschGodrey test for serial correlation in the residual was conducted. The very low probability in the Breusch-Godfrey Serial Correlation LM Test also strongly suggested the presence of serial correlation in the residuals.

The original specification was modified to address the serial correlation. The original specification was modified. Two approaches were adopted. One approach was to include lags of the variables and the other was to introduce an autoregressive (AR) term into the equation.

After the inclusion of the lags of the variables into the equation, the Durbin-Watson statistic of 2.02 showed that the equation was free of serial correlation. The Breusch-Godfrey Serial Correlation LM Test confirmed this result.

Including an autoregressive (AR) term is a common approach for accounting for serial correlation. This specification removes the lagged terms, replacing it with an $\mathrm{AR}(1)$ specification. After the inclusion of the AR(1) specification into the equation, the Durbin- 
Watson statistic of 1.90 showed that the equation was free of serial correlation, as indicated in Table 1. The Breusch-Godfrey
Serial Correlation LM Test once again confirmed this result.

Table 1

Least squares autoregressive model

\begin{tabular}{|l|c|c|c|c|}
\hline Variable & Coefficient & Std. error & T-statistic & Prob. \\
\hline LOG(GR01) & -0.655752 & 0.196435 & -3.338260 & 0.0024 \\
\hline LOG(WS01) & 0.201579 & 0.394241 & 0.511309 & 0.6131 \\
\hline LOG(R) & -0.211097 & 0.058114 & -3.632470 & 0.0011 \\
\hline LOG(YN01) & 0.456177 & 0.321231 & 1.420090 & 0.1666 \\
\hline LOG(G) & 0.326528 & 0.178508 & 1.829211 & 0.0780 \\
\hline LOG(T) & -0.188098 & 0.084921 & -2.214968 & 0.0351 \\
\hline C & -6.008825 & 4.728028 & -1.270895 & 0.2142 \\
\hline AR(1) & 0.462610 & 0.160715 & 2.878451 & 0.0076 \\
\hline R-squared & 0.955771 & Mean dependent var. & -2.453573 \\
\hline Adjusted R-squared & 0.944714 & S.D. dependent var. & 0.163796 \\
\hline S.E. of regression & 0.038513 & Akaike info criterion & & -3.482500 \\
\hline Sum squared residual & 0.041532 & Schwarz criterion & -3.130607 \\
\hline Log likelihood & 70.68500 & F-statistic & 86.43878 \\
\hline Durbin-Watson statistic & 1.901142 & Prob. (F-statistic) & 0.000000 \\
\hline Inverted AR Roots & \multicolumn{2}{|l|}{0.46} & & \\
\hline
\end{tabular}

While the two models are roughly comparable, the $\mathrm{AR}(1)$ model is preferred because of the somewhat smaller values for both the Akaike and the Schwarz information criteria. This model was therefore the one used for estimating the size of the informal economy.

All the coefficients of the explanatory variables have the expected signs; however, WS and $\mathrm{YN}$ were not significant at 10 per cent level of significance. The overall regression fit for the autoregressive model, as measured by the adjusted $\mathrm{R}^{2}$ value, indicated that 94 per cent of the variation in the currency demand was explained by the independent variables. The overall f-statistic showed a value of 86.43 indicating that the model was significant at a one per cent level. Even though these traditional test criteria are satisfactory, it was necessary to conduct a Whites heteroskedasticity test and Ramsey RESET test in order to detect heteroskedasticity and specification error in the equation. The f-statistic for the Whites heteroskedasticity test of 0.56 and probability of 0.84 indicated that the model did not display heteroskedasticity. The f-statistic for the Ramsey's RESET test of 1.28 indicated that the model was also not mis-specified.

\section{4}

\section{Estimates of the size of the informal economy}

Using the AR(1) model and the corresponding regression output, the size of the South African informal economy could be estimated. The GDP for the informal economy (GDPI), the formal economy GDP (GDP), the ratio of informal economy GDP to GDP (GDPI/GDP) are calculated and presented in Table 2. As the calculations of the informal economy are estimated indirectly (and by its very nature not directly observable), it is emphasised that these values are only broad estimates. 
Table 2

The informal and formal economy

\begin{tabular}{|c|c|c|c|c|c|}
\hline Date & $\begin{array}{c}\text { GDPI } \\
\text { (R millions) }\end{array}$ & $\begin{array}{c}\text { GDP } \\
\text { (R millions) }\end{array}$ & $\begin{array}{c}\text { GDPI/GDP } \\
(\%)\end{array}$ & $\begin{array}{c}\text { Nominal GDPI } \\
\text { growth rate } \\
(\%)\end{array}$ & $\begin{array}{c}\text { Nominal GDP } \\
\text { growth rate } \\
(\%)\end{array}$ \\
\hline 1966 & & 8,568 & & & \\
\hline 1967 & 2,330 & 9,559 & 12.0 & & \\
\hline 1968 & 2,614 & 10,340 & 12.5 & 11.5 & 7.9 \\
\hline 1969 & 2,757 & 11,654 & 11.8 & 5.3 & 12.0 \\
\hline 1970 & 2,985 & 12,791 & 11.1 & 7.9 & 9.3 \\
\hline 1971 & 3,590 & 14,136 & 11.6 & 18.5 & 10.0 \\
\hline 1972 & 3,956 & 15,953 & 11.5 & 9.7 & 12.1 \\
\hline 1973 & 5,446 & 19,740 & 12.2 & 32.0 & 21.3 \\
\hline 1974 & 6,287 & 24,277 & 11.5 & 14.4 & 20.7 \\
\hline 1975 & 7,172 & 27,323 & 11.0 & 13.2 & 11.8 \\
\hline 1976 & 8,051 & 30,848 & 10.0 & 11.6 & 12.1 \\
\hline 1977 & 9,213 & 34,261 & 9.9 & 13.5 & 10.5 \\
\hline 1978 & 11,140 & 39,416 & 9.9 & 19.0 & 14.0 \\
\hline 1979 & 13,212 & 47,100 & 10.1 & 17.1 & 17.8 \\
\hline 1980 & 17,711 & 62,730 & 10.7 & 29.3 & 28.7 \\
\hline 1981 & 17,944 & 72,654 & 9.9 & 1.3 & 14.7 \\
\hline 1982 & 18,828 & 82,462 & 9.6 & 4.8 & 12.7 \\
\hline 1983 & 19,401 & 94,350 & 9.0 & 3.0 & 13.5 \\
\hline 1984 & 21,073 & 110,584 & 9.4 & 8.3 & 15.9 \\
\hline 1985 & 23,040 & 127,598 & 8.6 & 8.9 & 14.3 \\
\hline 1986 & 31,800 & 149,395 & 9.0 & 32.2 & 15.8 \\
\hline 1987 & 37,352 & 174,647 & 10.1 & 16.1 & 15.6 \\
\hline 1988 & 40,756 & 209,613 & 9.2 & 8.7 & 18.2 \\
\hline 1989 & 52,778 & 251,676 & 8.8 & 25.8 & 18.3 \\
\hline 1990 & 60,262 & 289,816 & 8.2 & 13.3 & 14.1 \\
\hline 1991 & 65,727 & 331,980 & 7.7 & 8.7 & 13.6 \\
\hline 1992 & 70,297 & 372,225 & 7.4 & 6.7 & 11.4 \\
\hline 1993 & 79,880 & 426,133 & 7.7 & 12.8 & 13.5 \\
\hline 1994 & 91,155 & 482,120 & 8.4 & 13.2 & 12.3 \\
\hline 1995 & 104,470 & 548,100 & 8.3 & 13.6 & 12.8 \\
\hline 1996 & 105,699 & 617,954 & 8.1 & 1.2 & 12.0 \\
\hline 1997 & 111,535 & 685,730 & 8.2 & 5.4 & 10.4 \\
\hline 1998 & 101,128 & 738,926 & 7.4 & -9.8 & 7.5 \\
\hline 1999 & 114,644 & 800,696 & 8.1 & 12.5 & 8.0 \\
\hline 2000 & 117,110 & 888,057 & 7.7 & 2.1 & 10.4 \\
\hline 2001 & 133,975 & 982,944 & 7.8 & 13.5 & 10.2 \\
\hline 2002 & 133,904 & $1,098,714$ & 7.2 & -0.1 & 11.1 \\
\hline
\end{tabular}


While the size of the informal economy averages 9.5 per cent of GDP (GDPI/GDP) for the period as a whole, there is a clear decrease in the size of the informal economy relative to GDP during the period 1967 to 1993. From 1994 onwards, the size of the informal economy seems to be moving sideways, and ranges between 7.2 per cent and 8.4 per cent of GDP.

These estimates are comparable to previous estimates of the informal economy as a percentage of GDP. For example, this study estimates that for 1989 the informal economy as a percentage of GDP was 8.7 per cent. Hartzenberg \& Leimann (1992) also use a currency approach, and estimate that the informal economy in 1989 was 9 per cent of GDP. Loots (1991), using a labour market approach, estimates that for 1989 the informal economy made up 12.6 per cent of GDP. This higher figure is not surprising as results vary slightly depending on the estimation methods and statistical techniques that are used in the studies.

This study estimates that for 1993 the informal economy was 7.7 per cent of GDP. Martins \& Ligthelm (1995), using the October
Household Survey, estimate that for 1993 the informal economy as a percentage of GDP was 9.2 per cent. Martins \& Ligthelm (1995) acknowledge that their figure may be an overestimate, because the former homelands are excluded from their survey. The present results seem to confirm their suspicion. Martins \& Ligthelm (1995) estimate that for 1994 the informal economy as a percentage of GDP was 6.7 per cent. This estimate did however include the former homelands. This study estimates that for 1994 the informal economy was 8.4 per cent of GDP.

The 1999 revisions of the national accounts of South Africa estimated the level of the informal economy for 1995 at seven per cent of GDP (SARB, 2003). This contrasts with the estimate of 8.1 per cent of GDP in this study. While these values differ, it is important to note that the 1999 revised estimates of the national accounts included an estimate of the informal economy. This would result in an underestimation of the size of the informal economy as percentage of GDP for 1999 (and any subsequent years).

Figure 1

Informal Economy (\% of GDP)

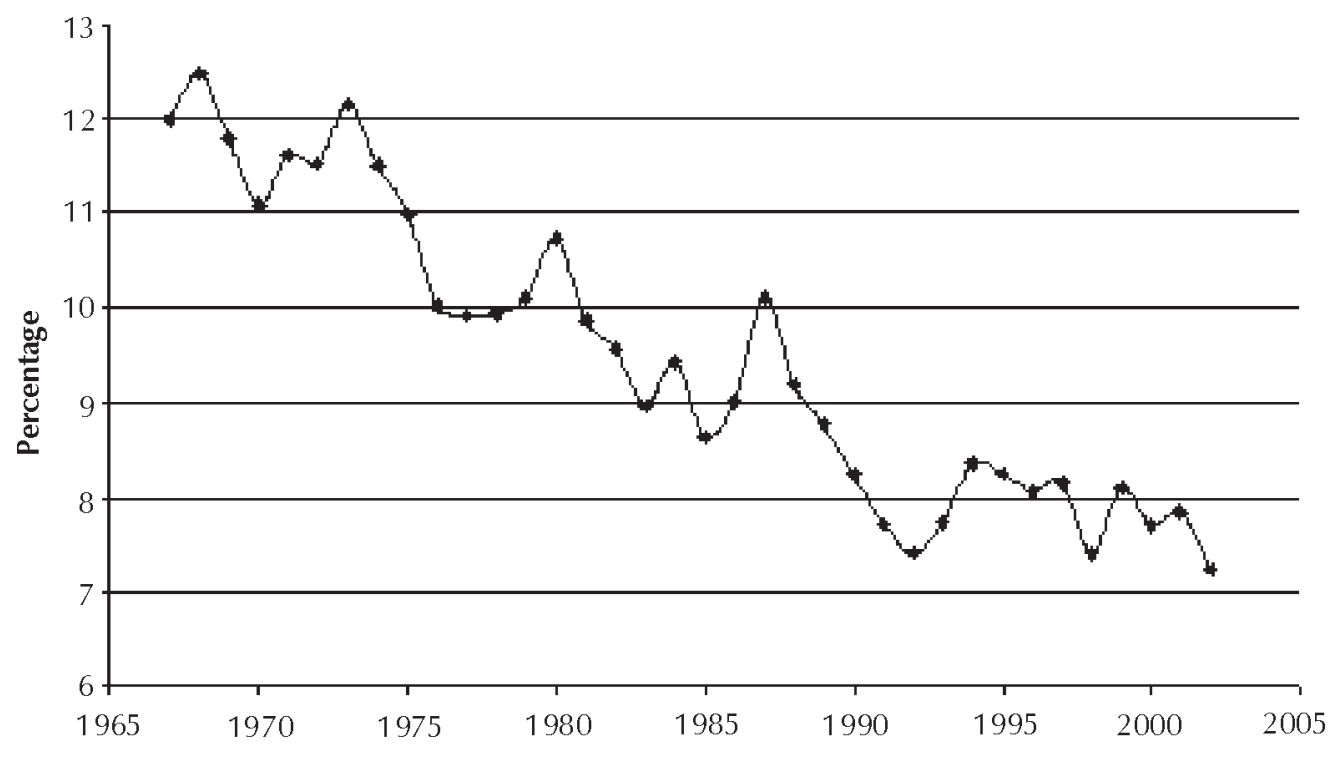

Date 
From Figure 1 it can be seen that the informal economy as a percentage of GDP consistently decreased from 1967 to 1993. Only in exceptional years (i.e. the oil crises of 1973 and 1979, and the crises followed by the $1985 \mathrm{debt}$ standstill) was there a slight increase in the informal economy as a percentage of GDP. After 1993 there was a levelling off of the informal economy between levels of 7.2 per cent and 8.4 per cent of GDP, as the Apartheid regulations on the informal economy began to collapse.

\section{5}

\section{The growth of the formal and informal economy}

Comparing the nominal growth rates of GDPI and GDP it can be seen in Table 2 that the informal economy had consistently underperformed in comparison to the formal economy over the period 1968-2002. Some real exceptions to this trend have been in years where there was either a global or national crisis, i.e. the $1973 / 78$ oil crises, and the 1986-89 sanctions crisis. However, closer examination shows that informal economic activity started to expand in the 1960's to reach a peak in the 1970s, after which it expanded at a much slower pace than formal economic activity (see Table 3 below). In the 1970s the average nominal growth in the informal economy outperformed average formal economic growth with 1.4 per cent. In the 1980s during the high inflation era and sanctions and disinvestment campaigns the underperformance of the informal economy was the most severe, showing that during tough economic times the informal sector cannot act as a safety net for the unemployed. It was also during this era that the structural imbalances in the South African economy caused the unemployment rate to increase. The inability of the informal economy to expand in order to accommodate the growing pool of unemployed since the 1980s, is therefore evident in the continuous underperformance of the sector to the formal economy.
Table 3

Nominal average growth comparisons between the formal and informal economies

\begin{tabular}{|l|c|c|}
\hline Period & GDPI (\%) & GDP (\%) \\
\hline $1968-1969$ & 8.4 & 10.0 \\
\hline $1970-1979$ & 15.7 & 14.0 \\
\hline $1980-1989$ & 13.8 & 31.1 \\
\hline $1990-1999$ & 7.8 & 11.6 \\
\hline $2000-2002$ & 5.2 & 10.6 \\
\hline
\end{tabular}

Source: Calculated from Table 2

\section{6}

\section{Causality between the formal and informal economy}

The causal relationship between the GDPI and GDP time series was tested using the Granger Causality Test. In order to conduct the Granger Causality Test it was necessary to determine the order of integration by using the Augmented Dickey Fuller Unit Root Test (ADF). The results show that GDPI and GDP both had unit root problems and had to be first-differenced. Once first-differenced, the GDPI and GDP time series still showed unit root problems, requiring the time series to be seconddifferenced. Once second-differenced, the GDPI and GDP time-series were integrated of second order and showed no unit root problems.

As the ADF showed that the GDPI and GDP time series were non-stationary, it was possible to test for co-integration. It was found that the variables GDPI and GDP were co-integrated at both a 5 per cent and a 1 per cent level of significance. This means that the results of the causality test are meaningful, and showed a long-term relationship between the two variables.

It is evident from the results in Table 4 that a unidirectional causality ran from GDPI to GDP, implying that Granger causality ran one-way from GDPI to GDP and not the other way. This result could indicate that an increase in the size of the informal economy contributed to the increase in the GDP in South Africa during the period under discussion. These findings largely 
support Giles et al (1999), who found strong evidence of Granger causality running from the informal economy to the formal economy for Canada and New Zealand during the period 1975-1995.

\section{Table 4}

Causality between the informal and formal economy

\begin{tabular}{|c|c|c|}
\hline Null hypothesis: & F-statistic & Probability \\
\hline $\begin{array}{l}\text { GDP does not Granger } \\
\text { cause GDPI }\end{array}$ & 2.22309 & 0.12640 \\
\hline $\begin{array}{l}\text { GDPI does not Granger } \\
\text { cause GDP }\end{array}$ & 4.24894 & 0.02408 \\
\hline \multicolumn{3}{|c|}{7} \\
\hline \multicolumn{3}{|c|}{ Conclusion } \\
\hline
\end{tabular}

While measuring the size of the informal economy using the Currency Demand Approach is problematic in the sense that the informal economy cannot be measured directly, the time series results are largely confirmed by other studies which use a number of approaches. While the results matched similar approaches, it was not surprising that the results vary slightly from those obtained by studies which use different estimation approaches and statistical techniques (such as the labour market approaches).

Coincidentally, it is interesting to note that the informal economy as a percentage of GDP decreased during the Apartheid era when government policy actively discouraged blackowned informal enterprises. It was only with the change of government in 1994 that the informal economy began to remain relatively constant. It would be interesting then to investigate if the reconstruction initiatives of the ANC government, particularly the 1995 White Paper on a National Strategy for the Development and Promotion of Small Businesses contributed to the support and promotion of the size of the informal economy or if this was just a spurious result.

While Statistics South Africa (2001) data suggest that the number of individuals working in the informal economy has increased significantly, the informal economy as a percentage of GDP has - as has been demonstrated here - decreased. This corroborates the view expressed by Abedian \& Desmidt (1990) that, if the number of individuals in the informal economy is increasing faster than the output, average earnings in the informal economy must be decreasing. This then raises the question of the impact of the informal economy on the perpetuation of poverty and inequality in South Africa.

The average nominal growth in the informal economy reached a peak in the 1970 s and has since then consistently underperformed in relation to the formal economy. This provides evidence that the informal economy has limited income earning opportunities and cannot act as a temporary safety net for the large number of unemployed and poor in South Africa.

Finally, the results of the causality test suggested that macro-economic policies aimed at the formal economy will not necessarily 'trickle down' to the informal economy, while macro-economic policies aimed at the informal economy may well have a profound effect on the formal economy.

\section{Endnote}

1 This article is based on Stephen Saunders' D.Com Thesis obtained from the University of Johannesburg in 2005.

2 Calculated from the South African Reserve Bank's Quarterly Bulletin database.

3 See Statistics South Africa, 2003.

4 In the event that other means of payment for informal transactions are made, the estimates based on these assumptions will more likely result in conservative estimates of the informal economy. These assumptions also exclude other means of transactions (such as barter exchange) that do take place in South Africa. Due to the nature of these transactions it would be impossible to include them. Abedian and Desmidt (1990: 414) found that the informal economy mostly uses cash transactions in South Africa. 


\section{References}

1 ABEDIAN, I. \& DESMIDT, M. (1990) "The informal economy in South Africa", The South African Journal of Economics, 58(4): 404-24.

2 BAGACHWA, M.S.D. \& NAHO, A. (1995) "Estimating the second economy in Tanzania", World Development, 23(8): 1387.

3 DEVEY, R.; SKINNER, C. \& VALODIA, I. (2003) "Informal economy employment data in South Africa: A critical analysis", Paper presented at the DPRU/TIPS Forum, 8-10 September, Johannesburg.

4 DOBOZI, I. \& POHL, G. (1995) "Real output declines in transition economies: Forget GDP, try power consumption data", Transition (6): 1-2.

5 EVIEWS (2000) EViews 4.0 User's Guide, Quantitative Micro Software: Irvine California.

6 FREY, B.S. \& SCHNEIDER, F. (2000) "Informal and underground economy", In International Encyclopaedia of Social and Behavioural Science, Ashenfelter, O. (ed.) Elsevier Science Publishing Company: Amsterdam.

7 GILES, D.; TEDDS, L. \& WERKNEH, G. (1999) "The Canadian underground and measured economies: Granger causality results", unpublished paper, University of Victoria, Victoria.

8 HARTZENBERG, G.M. \& LEIMANN A. (1992) "The Informal economy and its growth potential”, In Economic Growth in South Africa. Abedian, A. (ed.) Oxford University Press: Oxford.

9 LACKO, M. (1998) "The hidden economies of visegrad countries in international comparisons: A household electricity approach", In Hungary: Towards a Market Economy, Halpern, L. \& Wyplosz, C. (eds.) Cambridge University Press, Cambridge.

10 LOOTS, A.E. (1991) "Die belangrikheid van die informele sektor in die Suid-Afrikaanse ekonomie", Masters dissertation, Rand Afrikaans University: Johannesburg.
11 MARTINS, J.H. \& LIGTHELM, A.A. (1995) The Informal Sector of the South African Economy, Bureau of Market Research, University of South Africa: Pretoria.

12 PRINSLOO, J.W. (1999) "South Africa's national accounts: An overview of sources and methods", South African Reserve Bank Bulletin, June: 1-60.

13 QUANTEC (2003) "Formal and informal employment annual average estimates", Unpublished raw data, http://www.quantec.co.za (accessed 12 December 2003).

14 SCHAEFER, K.K. (2001) "Macroeconomic implications of an urban informal sector: A theoretical model and a South African case study", unpublished doctoral thesis, American University: Washington.

15 SCHNEIDER, F. (1986) "Estimating the size of the Danish shadow economy using the currency demand approach: An attempt", The Scandinavian Journal of Economics, 88(4): 193212.

16 SCHNEIDER, F. \& ENSTE, D. (2003) The Shadow Economy: An International Survey, Cambridge University Press: Cambridge.

17 SOUTH AFRICAN RESERVE BANK (2003) South African Reserve Bank Quarterly Bulletins, http://www.resbank.co.za (Accessed 12 June 2003).

18 STATISTICS SOUTH AFRICA (2001) Labour Force Survey P0210 (September), Statistics South Africa: Pretoria http://www.statssa.gov.za (Accessed 12 December 2002).

19 STATISTICS SOUTH AFRICA. (2004) Labour Force Survey P0210 (March), Statistics South Africa: Pretoria, http://www.statssa.gov.za (Accessed 14 March 2005).

20 TANZI, V. (1982) The Underground Economy in the United States and Abroad, Lexington Books: Lexington Massachusetts. 